RESEARCH ARTICLE

\title{
Student Experience and Quality of Tertiary Education for Students with Disabilities in Lesotho
}

\author{
Paseka Andrew Mosia ${ }^{\star} \&$ Tlakale Nareadi Phasha ${ }^{\star \star}$
}

\begin{abstract}
Access to tertiary education in the least developed countries, such as Lesotho, continues to be a rare experience for persons with disabilities who, despite being admitted to studies, struggle with meaningful participation. This article explores student experience of persons with disabilities studying at the National University of Lesotho. A combination of convenience and snowballing sampling techniques were used to recruit 15 staff members and 11 students enrolled in various programmes. A combination of individual semi-structured interviews and a focus group discussion were used to generate data. Findings reveal that various dimensions of student experiences are negatively affected. Students with disabilities encounter mobility challenges due to an inaccessible built environment; lecture timetables are not adapted to suit the needs of students with mobility challenges, blind students are not informed of potholes that are left uncovered and the students' request for their hostel to be adapted is not addressed. Additionally, students are not readily supported by their lecturers while some are subjected to bullying which goes unpunished and the victims receive no counselling for the resultant trauma. These factors affect the students' welfare and have an effect on their academic participation. The students are simply expected to conform to university practices. The summary of student experience, if used for assessment of quality education, demonstrates inequitable access to education for persons with disabilities. The study concludes that the institution provides poor-quality education as it fails to address the support needs of students with disabilities. The study recommends development of policies and practices that promote equity, and that student experience can be used to inform how the institution may improve access and the quality of its programmes. Equally, this study challenges students with disabilities to assert their right to an inclusive and equitable quality education.
\end{abstract}

\section{Keywords}

ableism; equitable access; quality education; student experience; students with disabilities;

tertiary education

* Dr Paseka Andrew Mosia is a Senior Lecturer, Educational Foundations Department, National University of Lesotho. Email: mosia296@gmail.com

** Prof. Tlakale Nareadi Phasha is a Professor at the Department of Inclusive Education, University of South Africa.Email: phashnt@unisa.ac.za 


\section{Introduction}

Despite massification of higher education in recent years, research on equality of access reveals huge disparities skewed in favour of students from middle- to high-income families (Webb, Watson, Cook \& Arico, 2017). There is a clear trend that shows students from minority groups, disadvantaged backgrounds and the disabled as underrepresented (Thiele, Singleton \& Pope, 2016). Reflecting on differences in access Read, Archer and Leathwood (2003, p. 262) observe that as a result of inequality in society "students from 'non-traditional' backgrounds are also disadvantaged by an institutional culture that places them as 'other"”. This undoubtedly compromises student experience and quality of higher education for the vulnerable groups who are expected to prove their worth at this level of education.

Research on assessing quality of education at tertiary level describes student experience as broader than the delivery of curriculum in lecture halls to include students' social and emotional experiences of studying at this level (Benckedorff, Ruhanen \& Scott, 2009). Harvey, Burrows and Green (1992, p. 1) argue that "the key factor in the assessment of quality in higher education is the student experience". Student experience reflects what they describe as 'total student experience' consisting of participation in academic activities and support of students' social and emotional needs. It addresses the academic and emotional aspects of student development which enhance the quality of education (Burrows, Harvey \& Green, 1992). As Tan, Muskat and Zehrer (2016, p. 213) note, student experience at higher education level means, "teaching and learning experiences... which now increasingly include the student encounter with administrative and support services that a HEI provides". Therefore, effective teaching at tertiary level seeks to address students' cognitive and affective goals (Vnouckova, Urbancovava \& Smolova, 2017). The quality of student experience is enhanced when university staff not only engage students academically but also readily support the emotional needs of vulnerable students (Hill, Lomas \& MacGregor, 2003). For example, McGregor, Langenfeld, Horne, Oleson, Anson and Jacobson (2016) argue that retention of students with disabilities at tertiary level is affected by the extent to which they feel integrated in an institution's social and academic context. Student experience, therefore, requires well-coordinated efforts from various university sectors to effectively meet students' academic and psychosocial needs. In line with principles of inclusive education, when disability support is integrated within a university support structure for all students, it is less likely to make students with disabilities feel discriminated against and marginalised (Nel, Nel \& Hugo, 2016).

Customarily, tertiary institutions mandate student affairs units to provide support services that enhance student experience and thus, contribute to quality in higher education (Ciobanu, 2013). In this regard, Luescher-Mamashela, Moja and Schreiber (2013) argue that student affairs departments need to adopt a holistic model and broaden their service mandate in order to achieve total student experience. They could provide comprehensive co-curricular and extra-curricular services and programmes that address students' personal needs to enhance student experience (Pansiri \& Sinkamba, 2017). However,Yakaboski and Birnbaum (2013) state that student affairs units at Kenyan higher education institutions are under-resourced and therefore deficient in providing required student experience. 
Another study conducted at one institution in the United Kingdom found that support services were not adequately coordinated to address the needs of students with disabilities (Pudaruth, Gunputh \& Singh, 2017). Similarly, in reflecting on student experience at the University of Botswana, Pansiri and Sinkamba (2017) reveal that the institution finds it easy to finance academic programmes while downplaying the role of psychosocial support for fruitful student experience. This makes a minority group such as students with disabilities most unlikely to receive support which enhances their experience. Thus, Kearney and Kane (2006) describe student experience for the disabled at tertiary institutions globally as undermined by an exclusionary culture. Ableism dominates education provision at this level. In describing inclusive education in South Africa, Howell (2006, pp. 165-166) states that denying students with disabilities opportunity for equitable access to higher education "reinforce[s] the notion that disabled students do not have a future in higher education".

\section{Conceptual and Theoretical Framework}

Social constructionism underpins the underlying values and ideologies that justify social practices reflected in students' experiences of access. This model describes persons with disabilities as oppressed and in need of advocacy for "creating a barrier-free society and developing a positive identity" for them as a minority group in society (Anastasiou \& Kauffman, 2011, p. 371). Lalvani and Broderick (2013) see this discrimination as influenced by ableism, tracing its orientation from the medical model of disability. Consequently, institutional failure to accommodate the inevitable human variability is blamed on students with disabilities as failing to meet programme requirements (Skrtic, 1991). Access to education at tertiary level is pervaded by normalcy disguised as fairness where everyone is required to conform (Madriaga, Hanson, Kay \& Walker, 2011). In trying to interpret this divergent view of life the social constructionist model explains this understanding of disability as a consequence of the power dynamics in society where the dominant oppresses the less privileged and creates systems which normalise inequality (Anastasiou \& Kauffman, 2013). Domination by the able-bodied majority normalises exclusion of the needs of persons with disability from participating equally in mainstream education (Liggett, 1988).

From this perspective, student experiences do not form the basis for evaluating the quality of education as all students are expected to comply with predetermined institutional standards despite their diversity. This creates a situation where having a disability negatively impacts one's self-concept and emotional well-being because it "keeps them from working and limits their social life" (Darling \& Heckert, 2010, p.137), making students with disabilities less likely to demand conditions equitable to their peers without disabilities. Consequently, social constructionism challenges the discriminatory public policy and requires persons with disabilities to acknowledge challenges of having a disability but promote conditions where "stigma-based identity" is replaced by "disability pride" (Darling \& Heckert, 2010, p. 133; Retief \& Letšosa, 2018, p. 5). 


\section{Contextualising Students' Experiences in Lesotho}

The needs of students with disabilities at secondary and tertiary education sectors in Lesotho have received inadequate attention, thus compromising their student experience (Mosia, 2014; Mosia \& Phasha, 2017). First, they are underrepresented at tertiary level. Aastudy by the Council on Higher Education (CHE) in Lesotho revealed that in 2011 only two higher education institutions out of 13 registered with $\mathrm{CHE}$, had enrolled a total of 10 students with disabilities. This number accounted for $0.09 \%$ of an age group of 18-35 persons with disabilities who could benefit from tertiary education, and was only $0.02 \%$ of the tertiary student population in Lesotho (CHE, 2012, p. 13). In 2014, 20 students with disabilities were enrolled at three institutions representing only $0.8 \%$ of the tertiary student population and $0.58 \%$ of persons with disabilities eligible for tertiary education (CHE, 2014, p. 36). Second, the students at both secondary and tertiary institutions face barriers such as inflexible curricula, inaccessible built environment and inadequate support services (CHE, 2012; 2014). While there is no policy promoting the right to education for learners at secondary school level, the promulgation of Higher Education Policy (HEP) gives impetus to tertiary institutions to improve access for this minority group of students. For example, section 8.3.5.2(c) of the Higher Education Policy (HEP) commits CHE to "... monitor the efforts of HE institutions, both public and private, to accommodate students with disabilities" (Kingdom of Lesotho, 2013, p. 36).

The National University of Lesotho as the focus of the current study has entrusted psychosocial support for students in the Department of Student Affairs and certain members of the academic staff working as year-level tutors but there are no specific support structures for students with disabilities. For example, subsection 3 of Ordinance No. 8 reads:

The Faculty/Personal Tutors shall be elected by the Faculty for a period of two years with the duty of assisting with and coordinating the Orientation, Registration, Counselling and preparation of academic results of students (National University of Lesotho [NUL], 2006).

The combined effect of services provided by this cadre of professional and welfare staff at the institution needs to be scrutinised. For example, Mosia and Phasha (2017) note deficiencies in the university support services for students with disabilities which are typical of the notion of ableism. They cite lack of attention to the students' needs during admission through to running academic programmes. The students have limited access to teaching and learning resources, information and communication technological (ICT) resources, including assistive devices.

Additionally, poor access is typified by blind students being denied access to programmes in certain faculties on the basis of assumed weaknesses (Matlosa \& Matobo, 2007; Mosia \& Phasha, 2017). For example, blind students are only admitted into programmes offered by the Faculties of Law, Education and Humanities because they lack competence in Mathematics and Statistics which form the basic requirement for other programmes (Mosia \& Phasha, 2017). However, the emphasis on skills students lack downplays the institution's lack of resources to teach Mathematics and Statistics to blind students. As such, the influence of Higher Education Policy mandating institutions to 'safeguard the right 
of equitable access to higher education for people with disabilities' (Kingdom of Lesotho, 2013, p. 36) is minimal. This calls for a critical re-evaluation of the institutionalised culture of exclusion typical of academic programmes generally and tertiary education programmes in particular. In an effort to depict nuances in the student experience of this minority group, the article used the following questions as guidelines:

1. How do students with disabilities experience access to education at the National University of Lesotho?

2. What values do the 'student experience' reflect about the institution's access practices?

\section{Research Methodology}

This study is a qualitative exploratory case study that is inductive, subjective and contextual (Morgan, 2014). A single case study design was most appropriate to capture the typical everyday life experiences of students with disabilities studying at a higher education institution (Bryman, 2012). It was a narrative enquiry into the students' unique experiences with staff, peers and social life at the university (Morgan, 2014).

\section{Research location and participant selection}

National University of Lesotho was established in 1945 as a Catholic institution affiliated with the University of South Africa (NUL, 2006). The Council on Higher Education reports that the university admits $43.9 \%$ of the country's undergraduate student population and an even higher percentage, $89.4 \%$, of the postgraduate student population with 11363 as the total number of students enrolled at the institution in 2011/2012 (CHE, 2012). This institution was selected as a research location for a doctoral study completed in 2017 with the University of South Africa and the study met basic ethics standards and posed minimal threat to the well-being of the participants. These include: informed consent, protection against harm, reciprocity, anonymity and confidentiality.

The study adopted purposive and snowballing techniques to identify a total sample of 15 members of staff and 11 students with disabilities. Purposive sampling identifies "information rich" cases (Patton, 2002). Incidentally, all staff participants and the first three students were selected purposively. As the institution lacked records of students with disabilities, snowballing was used to identify students for whom there was no readily available information about their disability statuses (Shaghaghi, Bhopal \& Sheikh, 2011). Therefore, the study relied on the three student participants and staff to identify other students with disabilities they knew and were willing to share their views. Subsequently, an additional eight students with disabilities were recruited as participants for the study.

The profile of staff participants included: 10 lecturers, some of which also worked as year-level Tutors in their faculties, one Librarian, one Welfare Officer, one Counsellor, one Admissions Officer and a Special Education Needs Assistant. Identified students were in three categories of impairments namely, visual impairment (5), physical impairment (5) and hearing impairment (1), and had enrolled in six different programmes at three different 
levels of study namely, Diploma (4), Bachelors' degree (6) and Postgraduate Diploma (1). In citing student participants, labels such as Participant 1 (P1), (P2) etc. will be used while career names such as Student Counsellor will be used for staff participants.

\section{Data Collection and Analysis Methods}

The study used semi-structured interviews to collect data from 15 staff members and 11 students. It also used a focus group discussion with a group of students.

\section{In-depth interviews}

The study deemed the use of semi-structured interviews most appropriate because they allowed participants to respond to questions liberally while allowing the study to gather participants' insight on the topic (Morgan, 2014). In-depth interviews were scheduled during the participants' free time. These took place at the university and lasted between 60 and 90 minutes. Participants (who happened to be Basotho nationals) were given the liberty to use Sesotho (their home language) or English for the interviews, while one Deaf participant was interviewed through the help of a Sign Language interpreter. All participants agreed to the interviews being audio-recorded.

\section{Focus group discussion}

Focus group discussions complement individual interviews in that they are able to generate ideas that mirror a social context (Breen, 2007) and the group provides a safety-net for members to express anxiety-provoking or unpopular ideas (Lederman, 1990). The exchange of ideas in focus group discussions brings new thoughts and reflections that an individual interview fails to give (Lederman, 1990). Five (two students with physical disabilities and three with visual impairments) of the 11 students who participated in the individual interviews were selected for a focus group discussion that took 90 minutes. The discussion was also audio-recorded.

\section{Data analysis}

Interpretative phenomenological analysis (IPA) was used to analyse data on participants' narratives on student experience (Smith, 2011). As Smith (2004) notes, one participant's transcript was studied to establish emerging ideas about student experience, then another, until all transcripts were studied. Only when all interviews were completed did we look for points of similarities and differences. Thus, analysis started with a scrutiny of individual cases and then a search for similar or different patterns across cases (Smith, 2011). Data coding helped discern patterns that led to a theoretical understanding (Babbie, 2014) of student experience and possible quality implications of the university programmes. The final analysis resulted in themes discussed in this study. Participants' views are depicted through verbatim citations under each theme (Larkin, Watts \& Clifton, 2006). 


\section{Results}

This article presents findings on student experiences ranging from inaccessible physical environments, unsuitable learning resources, staff attitudes and support for their psychosocial needs which have a bearing on the total student experience.

\section{Accessibility and suitability of infrastructure}

Students with disabilities reflected on how inaccessible built environments and delayed maintenance services in their hostels affected them. Students with mobility challenges had to use stairs to access lecture halls, had to navigate unpaved grounds with potholes, had poor lighting to access the library at night, walked between lecture halls which are far apart, and had to use furniture not adapted to their needs.

\section{Access to in-built environment}

Three students encountered challenges using stairs to access lecture halls and one of the three further expressed concern with the distance between the halls. For example, one student explains:

The fact that there are stairs says the infrastructure is not accessible for wheelchair users or those using crutches ... They admit a person who falls within their scope of education provision ... which university should I go to if my needs are not catered for in this university?

(Participant 1, a male student with cerebral palsy)

Another student explained:

As for lecture halls that require me to climb stairs ... you find that 'wow' I'll have a delay a bit, it is not a big deal. I told myself that, OK let me act as normal as I could, and climb the stairs and just shut up about that ramp to the building.

(Participant 2, a male student with a physical disability)

Despite a medical record thoroughly explaining a student's potential challenge with the use of stairs no adjustment was made to the timetable to ensure her classes are on the ground floor. She states:

So we have to go to the stairs in order to reach some classes [but] my doctor explain[ed] the nature of my disability and some of the things that they have to be aware of, like in winter I don't have to use stairs.

(Participant 3, a female student with cerebral palsy)

Students have a 10-minute allowance to move between successive classes. When classes are scheduled in lecture halls that are far apart, the time is inadequate for a student with mobility challenges to be on time for the next class as Participant 3 reflects:

You find that I have 08:00 o'clock class in my faculty and 09:00 o'clock class at the BTM, so it means I have to walk long distances; when I arrive in class I'd find the lecturer has covered much and I've missed so many things. For the timetable, I don't think they even think about me. 
Student experience indicates that the built environment acts as a barrier to their learning. This is corroborated by staff. For example, the Faculty of Humanities lecturer said of one student:

Her type of disability was such that it was hard for her to attend some of the classes in the halls that were in the upper rooms. That was one thing, the second thing was, sometimes the rooms were so separated that it would allow only students who are said to be able to move from one hall to the other [timeously].

Similarly, a student counsellor observes:

Eh, most of the administrative buildings are upstairs and there's no easy way to access such. It's quite a challenge.

Evidently, the institution makes limited efforts to accommodate mobility needs of students with physical impairments. The students adapt to existing structures despite potential challenges to their academic needs and physical health. Walkways around campus have not been adapted.

\section{Students' ease of movement}

Three students, one blind, another partially sighted and the third with a physical disability, described how lack of paving at the university posed mobility challenges for them. For example, one student recounted:

I arrived here in 2013 and there was that [uncovered holes] condition when I arrived and I reported it. The Special Education Needs Assistant tried to talk to maintenance staff but they didn't do anything. Instead in early 2014, they opened other holes.

(Participant 5, a male blind student)

Participant 5 added:

I think the way has to be paved enough. For instance when it rains I can't walk freely; there is some water along the way, they [pavements] are not well structured, the movement is not easy because of structuring of the university ... there are places that are not paved at all.

Though partially sighted and using spectacles, one student cited comparable challenges with her mobility around campus. She noted:

When I was in first year I think I fell five times here on campus. I still remember in Titanic (hall of residence) I fell when going to buy food because maybe my mind was not on the way, I fell, had some scratches, then fell again. Well, I fell a couple of times but with time you get used to the place and you know where you can walk carefully.

(Participant 6, a female student with visual impairment)

As a student with a physical disability and using crutches, Participant 2 stated:

The reason I mostly get discouraged to use the library is that during the day one attends classes. Then you have to go to the library late in the night, so I don't travel at night because of darkness. There're lights here and there so I'm afraid I might fall. 
Similar to inaccessible built environments, lack of paving creates mobility challenges to students with both visual and physical impairments and restricts their academic participation. Student experience is also hampered by unsuitable seating arrangements in lecture halls as explained below:

\section{Suitability of furniture}

Furniture in lecture halls and laboratories does not meet the students' needs as reported by two participants. For example, Participant 3 explained:

We have these long tables and long chairs, because, I assume it's because they're saying it's a lab, so everything has to be up ... I have problem with them, even though I happen to learn how to use them.

Similarly, another student complained about unsuitable furniture:

The chairs in class, some are not, in fact none is comfortable for us people with physical disabilities. When seated on a chair I can't reach the height of a desk, so I use my lap for supporting my book to write or I stand on my feet to be able to use a desk.

(Participant 4, a female student with dwarfism and Kyphosis conditions)

Furniture was not adapted to accommodate the needs of students with disabilities and this negatively affected their learning conditions.

\section{Students' interaction with academic staff}

Students with disabilities express various experiences from working with the academic staff. The experiences reflected two attitudes as follows: (a) supportive and (b) indifferent.

\section{Supportive attitudes}

Four students with disabilities considered at least one of their lecturers as tolerant and supportive and they shared experiences of positive support as follows:

It's been like it's only my ELG [linguistic course] lecturer who had taken the initiative to ensure that actually I get an enlarged question paper when I write my exams. So in that sense, it put me in a position to say it [support] is actually at the low ebb.

(Participant 7, a male student with visual impairment)

Another student indicated:

... it's only one lecturer who has consistently given me notes.

(Participant 8, a male student with visual impairment)

Similarly, Participant 6 recalled:

I had a lecturer who, I did statistics, understood the situation and all that, she gave me notes. 
Conversely, one student shared:

OK for now eh, many lecturers are giving me notes, they give me notes every day after the lecture because I cannot write and my interpreter cannot write as well because she's a student.

(Participant 9, a female deaf student)

However, not all lecturers' initiatives of support were perceived as suitable. For example, Participant 3 is offended by lecturers who pay too much attention to her unique physical appearance. She explained:

I don't need to be treated that much special, I assume they take great care for me because sometimes there're these ones who think I cannot do anything and I feel like 'wow' how should it be like this? You think I'm with disability but I can do anything, it doesn't stop me to do anything. They look at us as if we are not people.

Participants, except for the deaf student, remember a few supportive attitudes. Further, not all lecturers' apparently good intentions have desired effects; they were insensitive to the student's impairment.

\section{Indifferent attitudes}

Excerpts from four students exemplify incidents where the students felt ignored by the institution and lecturers in their teaching despite their need for support.

\section{Participant 5 opined:}

It's [support] not voluntary, I'll have to tell them first, yes I still have to approach them... some I have approached but the time for exams will arrive without having nothing, and it`s happening even now.

He added:

When they teach, they don't take any consideration that there's a visually impaired learner in that class ... who cannot see what they are pointing at.

Similarly, Participant 8 explicated:

Other lecturers might have just been forgetful, which is human, while others normally said they knew nothing about me. You could see that they were trying and at times they just forced themselves to work with me. Some of them would say that they need to be trained before dealing with my needs but I would assure them that my challenges were not severe.

The observed indifference in lecturers discouraged the students from seeking support as Participant 1 stated:

One may understand and say they would email the notes or give you handouts but another does not even try and you might end up offending them because they are human ... It is not easy to report your problem to management several times because it appears as though you are seeking special attention or you are too demanding. You end up saying the best I can have is sufficient. 
Participant 9 relied on sign language interpretation to study, but there were delayed efforts to secure a Sign Language interpreter for her. She stated:

There were no preparations for me to be able to access information in class yet they knew that there was a deaf student admitted here. And I have to rely on that student who would be helping with interpreting services until I thought to myself the student won't be able to interpret during five years while I`m learning here.

The university seems not positioned to promote equitable access to its curricula and subsequently, it fails to mandate both academic and non-academic staff to accommodate the students' needs.

\section{Students' experience of bullying}

Students with disability explained that a hall of residence reserved for them was not adapted to address their needs. They live in one building and are expected to use the same bathroom and toilet as students of different genders. The residence is also poorly maintained. Socially, all but two students had courteous relationships with peers. Two students with physical disabilities presented contrasting experiences about their interactions with the general student population.

Participant 3 stated:

When you move around the campus, others look at you, gossip about you, and end up laughing. You feel like 'wow!' Why should they laugh, is there anything wrong with me? I prefer people who come to me and ask, what happened? They look at us as if we are not people, we are something that they can make fun of. They'll just look at you, especially ladies ... And then when you turn back and look at them, they can make these funny laugh that you can say, 'how can these people do this?'

Participant 4 revealed:

Other students call me [names] ... The environment is OK because my classmates have accepted me and help me where possible, for instance, on the stairs, disabled people are not easily recognised when it is congested. My classmates do shield me so that I'm not pushed around.

Verbal discriminatory gestures from peers only serve to confirm an environment which is not receptive of the needs of students with disabilities.

\section{Staff perspectives of student experience}

The following are examples of staff perspectives on their role in enhancing the student experience.

A Faculty of Education (FED) lecturer working as a year-level tutor noted:

Sometimes you may not even notice. I just happen to notice this one (referring to a student with visual impairment) because this particular student in my class is a very interactive student, otherwise I wouldn't know ... if there are others besides this one I don't know. 
A Business Administration (BA) lecturer who also worked as a year-level tutor shared these sentiments:

Sometimes you come to class, have one hour to deliver, they're already seated, the person is in the middle, you cannot identify disability or anything.

The excerpts of the two participants indicate that it is difficult for lecturers to identify students with disabilities in their classes and they do not deal with students as individuals. It was evident that tutors who were employed to provide psychosocial support could not provide it to students with disabilities if they could not identify them in their classes.

Moreover, any academic staff deployed as tutors are not selected on any criteria related to skills in psychosocial support. For example, the BA lecturer noted:

We are not equipped, in fact I'm not equipped enough to do counselling but one would think of maybe academic counselling, but definitely we are less equipped. We need to be equipped further as to how we execute the counselling part of it.

A lecturer at the university's Institute for Extra Mural Studies (IEMS), also assigned tutorship, avers:

As a coordinator I just do it [counselling] eh, just haphazardly because I`m not a counsellor but there are those arrangements and plans to have one [person] to address their psychosocial needs ... Much of my work is towards administrative issues. I am also teaching though I am not teaching first year, which is the level where the student in question is.

A Sociology lecturer opined:

The tutor is not for a particular class, but for a faculty. In FSS for example, students in one year level are in excess of two thousands, so I cannot just handle everything. I don't know how to put it but it is basically an overarching thing. It's not individual cases because look I am still a lecturer. I teach, I go to class, I have my own students, and I have my own department.

The BA Lecturer could not estimate the number of students of the year level he tutors. He expressed:

I can't have the exact number but it's roughly around sixteen programmes.

Tutors lack skills to support the students generally. Therefore, addressing the needs of students with disabilities could be a greater challenge when they are not trained. There are multiple challenges to tutorship as evident in participants' views above. Lecturers are assigned tutorship to year level and programmes in which they do not teach and across programmes outside their departments. Tutors deal with high volumes of students' needs and may not pay attention to a particular group of vulnerable students.

Correspondingly, at the time data were collected for this study the university had two student counsellors and two welfare officers to serve a student population of approximately 11000 students and a Special Education Needs Assistant to serve self-identified visually 
impaired students. It was established that there is no coordination of services from these three classes of staff. Asked about the quality of support for students with disabilities, the Student Counsellor states:

I would say really our students who are disabled are not supported. They are not supported at all.

\section{Discussion}

This study aimed to explore students with disabilities' experience of tertiary education at one university in Lesotho. It was conducted against the background where the country did not have a national policy on inclusive education. Nonetheless, the government committed itself to support persons with disabilities in tertiary institutions through HEP. Essentially, the disability support mandate is undermined by the university which, as any other learning institution in the country, does not have any established practice of providing an inclusive and equitable education. The following findings are evident from data presented above.

Although the university admits students with mobility challenges, it has not built ramps to enable them access to every building. These barriers do not only directly affect student experience with academic activities but also have a bearing on how they view themselves as persons with disabilities. For example, one student says he has to "act normal" and climb the stairs while another says she "learnt" to use tall laboratory chairs and tables despite possible detriment to her health. Students with disabilities are expected to adjust themselves to standards set for everyone else despite falling short of their needs as persons with disabilities. This depicts practices where the needs of minority groups are ignored and normality is used as a measure for participation in the education system.

As Lalvani and Broderick (2013) note, the university is unlikely to accommodate these student differences due to the ableism ideology dominant at this level of education. The students are expected to adapt because failure to do so would create an impression that they are less qualified for the university's programme requirements (Skrtic, 1991). Ableism is also evident in the lecturers' indifference towards the students' needs and discrimination by peers.

Eleven students with disabilities admitted at this university face various challenges. Those with visual and physical impairments have mobility challenges and there are no learning materials in appropriate formats for blind people. There were delays in securing an interpreter for the deaf student, Information and Communication Technology had not been adapted to their needs and lecturers are not trained or even mandated to support them. Students with disabilities have to learn "normally" like all students (Mosia \& Phasha, 2017).

The possible intervention by the Department of Student Welfare staff is undermined by understaffing. The staff is unlikely to focus on the needs of students with disabilities when such students or their needs are not identified and particularly when the student : counsellor or welfare officer ratio is high. The findings compare with previous research which found that reliance on the Welfare Departments to support students and contribute to quality education is undermined by poor resourcing of such departments (Yakaboski 
\& Birnbaum, 2013). Additionally, the university's deployment of academic staff to work as tutors without training them for the responsibility suggests it undermines the role of psychosocial support for student experience (Pansiri \& Sinkamba, 2017).

Therefore, Harvey et al. (1992) argues that quality education can be judged on total student experience which consists of successful fulfilment of academic and psychosocial needs of students. The National University of Lesotho does not provide quality education for students with disabilities because there is evidence that they encounter barriers to both academic and social participation (Burrows, Harvey \& Green, 1992). Moreover, according to Hill, Lomas and MacGregor (2003) one of the requirements for enhancing student experience is for lecturers to actively identify and address the needs of vulnerable students. However, the university fails to do so despite the mandate from HEP to all tertiary education institutions in Lesotho (Kingdom of Lesotho, 2013). Lecturers use the ableism principle to deal with students; students are forced to adapt to set standards or be viewed as unqualified to study at this level (Skrtic, 1991) while lecturers are not expected to adapt their lectures to individual needs.

\section{Conclusions}

This study demonstrates that the University excludes student with disabilities as a minority group, from full participation in its academic programmes. Buildings are constructed for the able-bodied and teaching and learning activities are not necessarily accessible to students with disabilities; all students adapt to the standard of academia set abstractly for all. This study challenges the institution to use student experience to assess the relevance of its programmes because students with disabilities have the right to equitable access to education. Ignoring the academic, social or emotional needs of a certain group of the student population is undermining the quality of education.

\section{References}

Anastasiou, D. \& Kauffman, J.M. (2011). A social constructionist approach to disability: Implications for Special Education. Exceptional Children, 77(3), 367-384. https://doi.org/10.1177/0014402911 07700307

Anastasiou, D. \& Kauffman, J.M. (2013). The social model of disability: Dichotomy between impairment and disability. Journal of Medicine and Philosophy, 38, 441-459. https://doi.org/10.1093/jmp/jht026

Babbie, E.R. (2014). The basics of social research. London:Wadsworth.

Benckedorff, P., Ruhanen, L. \& Scott, N. (2009). Deconstructing the student experience: A conceptual framework. Journal of Hospitality and Tourism Management, 16(1), 84-93. https://doi.org/10.1375/ jhtm.16.1.84

Breen, R.L. (2007).A practical guide to focus-group research. Journal of Geography in Higher Education, 30(3), 463-475. https://doi.org/10.1080/03098260600927575

Bryman,A. (2012). Social Research Methods. Oxford: Oxford University Press.

Burrows, A., Harvey, L. \& Green, D. (1992). Concepts of quality in higher education: A review of the literature. Birmingham: QHE.

CHE (Council on Higher Education) (2012). CHE report on the state of higher education in Lesotho. Maseru: $\mathrm{CHE}$.

CHE (Council on Higher Education) (2014). Council on Higher Education Annual Report. Maseru: CHE. 
Ciobanu, A. (2013). The role of student services in the improving of student experience in higher education. Procedia - Social and Behavioral Sciences, 92, 169-173. https://doi.org/10.1016/j.sbspro.2013.08.654

Darling, R.B. \& Heckert, D.A. (2010). Orientations toward disability: Differences over the life course. International Journal of Disability, Development and Education, 57(2), 131-143. https://doi.org/10.1080/ 10349121003750489

Harvey, L., Burrows, A. \& Green, D. (1992). Total student experience: A first report of the QHE National Survey of Staff and Students' views of the important criteria for assessing the quality of higher education. Birmingham: QHE.

Hill,Y., Lomas, L. \& MacGregor, J. (2003). Students' perceptions of quality in higher education. Quality Assurance in Education, 11(1), 15-20. https://doi.org/10.1108/09684880310462047

Howell, C. (2006). Disabled students in higher education in South Africa. In: B. Watermeyer, L. Swartz, T. Lorenzo, M. Schneider \& M. Priestley (Eds.), Disability and Social Change: A South African agenda, pp. 164-178. Cape Town: Human Science Research Council.

Kearney, A. \& Kane, R. (2006). Inclusive education policy in New Zealand: Reality or ruse? International Journal of Inclusive Education, 10(2\&3), 201-219. https://doi.org/10.1080/13603110500256145

Kingdom of Lesotho. (2013). Higher Education Policy. Maseru: Council on Higher Education.

Lalvani, P. \& Broderick A.A. (2013). Institutionalised ableism and the misguided 'Disability Awareness Day': Transformative pedagogies for teacher education. Equity and Excellence in Education 46(4), 468-483. https://doi.org/10.1080/10665684.2013.838484

Larkin, M., Watts, S. \& Clifton, E. (2006). Giving voice and making sense in interpretative phenomenological analysis. Qualitative Research in Psychology, 3(2), 102-120. https://doi.org/10.1191/ 1478088706qp062oa

Lederman,L.C. (1990). Assessing educational effectiveness:The focus group interview as a technique for data collection. Communication Education, 39(2), 117-127. https://doi.org/10.1080/03634529009378794

Liggett, H. (1988). Stars are born: An interpretive approach to the politics of disability. Disability, Handicap and Society, 3(3), 263-275. https://doi.org/10.1080/02674648866780261

Luescher-Mamashela, T., Moja, T. \& Schreiber, B. (2013). Towards a professionalisation of student affairs in Africa. Journal of Student Affairs in Africa, 1(1\&2), vii-xiii. https://doi.org/10.14426/jsaa.v1i1-2.18

Madriaga, M., Hanson, K., Kay, H. \& Walker, A. (2011). Marking-out normalcy and disability in higher education. British Journal of Sociology of Education, 32(6), 901-920. https://doi.org/10.1080/0142569 2.2011 .596380

Matlosa, L. \& Matobo, T. (2007). The education system in Lesotho: Social inclusion and exclusion of visually and hearing-impaired persons in institutions of higher learning. Review of Southern African Studies, 5(1\&2), 191-211. http://opendocs.ids.ac.uk/opendocs/handle/123456789/6395

McGregor, K.K., Langenfeld, N.,Van Horne, S., Oleson, J., Anson, M. \& Jacobson, W. (2016). The university experiences of students with learning disabilities. Learning Disabilities Research E Practice, 31(2), 90-102. https://doi.org/10.1111/ldrp.12102

Morgan, D.L. (2014). Integrating Qualitative and Quantitative Methods: A pragmatic approach. Los Angeles: Sage. https://doi.org/10.4135/9781544304533

Mosia, P.A. (2014). Threats to inclusive education in Lesotho: An overview of policy and implementation challenges. Africa Education Review, 11(3), 292-310. https://doi.org/10.1080/18146627.2014.934989

Mosia, P.A. \& Phasha N.T. (2017). Access to curricula for students with disabilities at higher education institutions: How does the National University of Lesotho fare? African Journal of Disability 6(0), a257. https://doi.org/10.4102/ajod.v6i0.257

Nel, M., Nel, N. \& Hugo, A. (2016). Inclusive education: An introduction. In: M. Nel, N. Nel \& A. Hugo (Eds.), Learner Support in a Diverse Classroom, pp. 3-33. Pretoria:Van Schaik Publishers. 
NUL (National University of Lesotho) (2006). National University of Lesotho 2006/2007 calendar. Roma: NUL.

Nusbaum, E.A. (2013).Vulnerable to exclusion: the place for segregated education within conceptions of inclusion. International Journal of Inclusive Education, 17(12), 1295-1311. https://doi.org/10.1080/136 03116.2013.826292

Pansiri, B.M. \& Sinkamba, R.P. (2017). Advocating for standards in student affairs departments in African Institutions: University of Botswana experience. Journal of Student Affairs in Africa, 5(1), 51-62. https:// doi.org/10.24085/jsaa.v5i1.2482

Patton, M.Q. (2002). Qualitative research and evaluation methods. Thousand Oaks, CA: Sage.

Pudaruth, S., Gunputh, R.P. \& Singh, U.G. (2017). Forgotten, excluded or included? Students with disabilities: A case study at the University of Mauritius. African Journal of Disability, 6(0), a359. https:// doi.org/10.4102/ajod.v6i0.359

Read, B., Archer, L. \& Leathwood, C. (2003). Challenging culture? Student conception of 'belonging' and 'isolation' at a post-1992 university. Studies in Higher Education, 28(3), 261-277. https://doi.org/ $10.1080 / 03075070309290$

Retief, M. \& Letšosa, R. (2018). Models of disability: A brief overview. HTS Teologiese Studies/ Theological Studies 74(1), a4738. https://doi.org/10.4102/hts.v74i1.4738

Shaghaghi, A., Bhopal, R.S. \& Sheikh, A. (2011). Approaches to recruiting 'hard-to-reach' populations into research: A review of the literature. Health Promotion Perspectives, 1(2), 86-94. https://doi. org/10.5681/hpp.2011.009

Skrtic, T.M. (1991). The special education paradox: Equity as the way to excellence. Harvard Educational Review, 61(2), 148-206. https://doi.org/10.17763/haer.61.2.0q702751580h0617

Smith, J.A. (2004). Reflecting on the development of interpretative phenomenological analysis and its contribution to qualitative research in psychology. Qualitative Research in Psychology, 1(1), 39-54.

Smith, J.A. (2011). Evaluating the contribution of interpretative phenomenological analysis. Health Psychology Review, 5(1), 9-27. https://doi.org/10.1080/17437199.2010.510659

Tan, A., Muskat, B. \& Zehrer, A. (2016). A systematic review of quality of student experience in higher education. International Journal of Quality and Service Sciences, 8(2), 209-228. https://doi.org/10.1108/ IJQSS-08-2015-0058

Thiele, T., Singleton, A., Pope, D. \& Stanistreet, D. (2016). Predicting students' academic performance based on school and socio-demographic characteristics. Studies in Higher Education, 41(8), 1424-1426. https://doi.org/10.1080/03075079.2014.974528

Vnoučková, L., Urbancová, H. \& Smolová, H. (2017). Factors describing students' perception on education quality standards. Journal on Efficiency and Responsibility in Education and Science, 10(4), 109-115. https://doi.org/10.7160/eriesj.2017.100403

Webb, R., Watson, D., Cook, S. \& Arico, F. (2017). Graduate views on access to higher education: Is it really a case of pulling up the ladder? Studies in Higher Education, 42(3), 504-518. https://doi.org/ 10.1080/03075079.2015.1052738

Yakaboski, T. \& Birnbaum, M. (2013). The challenges of student affairs at Kenyan public universities. Journal of Student Affairs in Africa, 1(1\&2), 33-48. https://doi.org/10.14426/jsaa.v1i1-2.34

How to cite:

Mosia, P.A. \& Phasha, T.N. 2020. Student Experience and Quality of Tertiary Education for Students with Disabilities in Lesotho. Journal of Student Affairs in Africa, 8(1), 13-28. DOI: 10.24085/jsaa. v8i1.3824 